\title{
PERANCANGAN SISTEM INFORMASI PEMASARAN DAN PENJULAN BERBASIS SMARTPHONE (ANDROID) PADA DEPOT AIR MINUM
}

\author{
Andi Muh. Lukman \\ Lulu2k7@gmail.com \\ Fakultas Teknik Universitas Pejuang Republik Indonesia (UPRI)
}

\begin{abstract}
Abstrak
Penelitian ini bertujuan untuk: (1) Merancang Perancangan Sistem Informasi Pemasaran dan Penjualan Berbasis Smartphone (Android) pada Depot Air Minum. (2) Mengimplementasikan Sistem Informasi Pemasaran dan Penjualan Berbasis Smartphone (Android) pada Depot Air Minum. Penelitian ini dilaksanakan pada bulan Mei sampai Agustus 2015 dengan lokasi penelitian di Depot Air Minum yang berlokasi di Pekkae Kec. Tanete Rilau Kab. Barru. Proses penjualan air minum pada Depot ini, masih menggunakan cara manual dan mengalami banyak kendala dalam pengolahan data seperti transaksi, perhitungan bonus karyawan dan pembuatan laporan penjualan. Oleh karena itu, penulis mencoba merancang sistem informasi dengan database terstruktur yang diharapkan mampu mengakomodir seluruh aktifitas bisnis dengan menggunakan Bahasa pemrograman PHP, MySQL, CSS, dan Java Scrip. Hasil penelitian menunjukkan bahwa sistem informasi dapat memudahkan dalam mengelola data pelanggan, data transaksi, penghitungan bonus bagi karyawan dan pemesanan air minum serta memudahkan dalam pembuatan laporan.

Kata Kunci: Sistem Informasi Pemasaran, Penjualan, Website, dan Smartphone (Android).
\end{abstract}

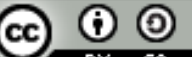

\section{Pendahuluan}

Depot Air Minum yang menjadi objek penelitian sampai pada tahun ini memiliki jumlah pelanggan kurang lebih seratus yang terdiri dari pelanggan toko, rumah, instansi/kantor, warung makan, dan lain-lain dan tranksaksi dalam satu hari mulai dari 30 sampai 70 tranksaksi atau dapat di rata-rata sekitar 50 tranksaksi. Tingginya jumlah permintaan dan pesanan air minum pada Depot, menjadi pemicu utama akan kebutuhan sistem informasi untuk membantu mengelola data dan informasi dalam menjalankan aktifitas bisnis ini. Karena dalam hal ini, sistem pelayanan konsumen menjadi prioritas utama yang harus diperhatikan dalam mengembangkan usaha ini.

Oleh karena itu, penulis mencoba merancang sistem informasi dengan database terstruktur yang diharapkan mampu mengakomodir seluruh aktifitas bisnis dengan menggunakan Bahasa pemrograman PHP, MySql, CSS, JavaScrip. Rancangan sistem informasi ini juga diharapkan, dapat memudahkan dalam mengelola data pelanggan, data penjualan, penghitungan bonus antaran pada karyawan dan pemesanan air minum serta memudahkan dalam pembuatan laporan. Rumusan masalah dalam penelitian ini adalah bagaimana merancang Sistem Informasi pemasaran dan penjualan air minum isi ulang berbasis Smartphone (Android) dan Bagaimana mengimpelementasikan Perancangan Sistem Informasi pemasaran dan penjualan air minum isi ulang berbasis Smartphone.

Penelitian ini dibatasi dengan membangun sistem yang hanya membantu mengolah data pelanggan, proses kelancaran data transaksi penjualan, perhitungan dalam setiap transaksi, penghitungan bonus karyawan, serta pembuatan laporan-laporan dan diharapkan sistem ini dapat memudahkan pelanggan dalam pemesanan air.

\section{Landasan Teori}

\subsection{Konsep Sistem dan Informasi}

Sistem adalah suatu jaringan kerja dari prosedur-prosedur yang saling berhubungan, berkumpul bersama-sama untuk melakukan suatu kegiatan atau untuk menyelesaikan suatu sasaran yang tertentu" [1]. Menurut [2] informasi adalah data yang telah diolah menjadi suatu bentuk yang penting bagi si penerima dan mempunyai nilai yang nyata yang dapat dirasakan dalam keputusan-keputusan yang sekarang atau keputusan-keputusan yang akan datang. Menurut [3] sistem informasi adalah suatu sistem di dalam suatu organisasi yang mempertemukan kebutuhan pengolahan transaksi harian yang mendukung fungsi operasi organisasi yang bersifat manajerial dengan kegiatan strategi dari suatu organisasi untuk dapat menyediakan kepada pihak luar tertentu dengan laporan-laporan yang diperlukan. 


\subsection{Konsep Basis Data}

Menurut [4] Basis data adalah suatu susunan atau kumpulan data operasional lengkap dari suatu organisasi/perusahaan yang di organisir dan disimpan secara terintegrasi dengan menggunakan metode tertentu dan komputer sehingga mampu menyediakan informasi optimal yang di perlukan pemakainya. Menurut [5] menyatakan bahwa basis data adalah suatu pengorganisasian sekumpulan data yang saling terkait sehingga memudahkan aktifitas untuk memperoleh informasi yang optimal. Database menagemen sistem (DBMS) merupakan perangkat lunak sistem yang memungkinkan para pemakai membuat, memelihara, mengontrol, dan mengakses basis data dengan cara yang praktis dan efisien. DBMS digunakan untuk mengakomodasi berbagai macam yang memiliki kebatuhan akses yang berbeda-beda.

\subsection{Android}

Android adalah sistem operasi yang berbasis Linux untuk telepon seluler seperti telepon pintar dan komputer tablet. Android menyediakan platform terbuka bagi para pengembang untuk menciptakan aplikasi mereka sendiri untuk digunakan oleh bermacam peranti bergerak.

\subsection{PHP (Personal Home Page)}

Pada tahun 1996, PHP telah banyak digunakan dalam Website di dunia. Sebuah kelompok pengembang software yang terdiri dari Rasmus, Zee Suraski, Andi Gutman, Stig Bakkenm Shane Caraveo dan Jim Winstead bekerja sama untuk menyempurnakan PHP 2.0. Pada tahun 1998, PHP 3.0 diluncurkan, penyempurnaan terus dilakukan sehingga pada tahun 2000 dikeluarkan PHP 4.0.Tidak berhenti sampai disitu, kemampuan PHP terus disempurnakan. PHP memiliki kelebihan [6].

\subsection{MySQL (Structured Query Language)}

MySQL adalah suatu Relational database management system (RDBMS) yang mendukung database yang terdiri dari sekumpulan relasi atau tabel. SQL distandardisasi sebagai bahasa untuk menciptakan database, menyimpan informasi ke dalam database, dan mendapatkan kembali informasi darinya [7].

\subsection{Konsep Pemasaran}

Pemasaran merupakan salah satu dari kegiatan pokok yang dilakukan oleh pengusaha mempertahankan kelangsungan hidupnya, untuk berkembang, dan mendapatkan laba. Menurut [8] pemasaran adalah sebagai suatu proses sosial dan manajerial dimana seseorang atau kelompok memperoleh apa yang mereka butuhkan dan usahakan melalui penciptaan, pertukaran yang dapat memenuhi kebutuhan, keinginan dan permintaan seseorang atau kelompok. Marketing mix merupakan salah satu konsep dalam pemasaran modern pada saat sekarang ini. Dimana konsep tersebut adalah salah satu kegiatan pemasaran yang sangat menentukan keberhasilan perusahaan dalam mengejar maksimum profit [9]. Dalam hal ini [10] memberikan pengertian marketing mix adalah empat variabel atau kegiatan yang merupakan inti dari sistem pemasaran perusahaan yaitu produk, struktur harga, kegiatan promosi dan sistem distribusi.

\subsection{Pengertian depot air minum}

Depot air minum adalah usaha industri yang melakukan proses pengolahan air baku menjadi air minum dan menjual langsung kepada konsumen. Proses pengolahan air pada depot air minum pada prinsipnya adalah filtrasi (penyaringan) dan desinfeksi. Proses filtrasi dimaksudkan selain untuk memisahkan kontaminasi tersuspensi juga memisahkan campuran yang berbentuk koloid termasuk mikroorganisme dari dalam air, sedangkan desinfeksi dimaksudkan untuk membunuh mikroorganisme yang tidak tersaring pada proses sebelumnya.

\subsection{Air minum}

Air minum adalah air yang melalui proses pengolahan ataupun tanpa proses pengolahan yang memenuhi syarat kesehatan dan dapat langsung di minum (Keputusan Menteri Kesehatan Nomor: 907 Tahun 2002). 


\section{Metode}

\subsection{Analisis Sistem}

Sistem yang ada pada Depot Air Minum Nursakinah masih menggunakan cara manual tanpa terkomputerisasi dalam proses pengelolaan data pelanggan, pesanan air minum dan transaksi penjulan, mengakibatkan kegiatan usaha tidak berjalan secara maksimal dan efisien Untuk lebih jelasnya, alur proses penjualan pada Depot Air Minum Nursakinah (DAMIU). Berdasarkan hal tersebut di atas, maka penulis mengusulkan untuk merancang suatu Sistem informasi Penjualan Air Minum untuk memberi kemudahan kepada manajemen Depot Nursakinah untuk mengontrol Data pelanggan, data-data piutang pelanggan, bonus gaji karyawan, dan memudahkan pengelolaan data transaksi serta laporan-laporan penjualan. Sistem yang diusulkan menjelaskan bahwa:

1. Calon pelanggan dapat melakukan pedaftaran secara online melalui web maupun smartphone yang menggunakan OS android.

2. Pelanggan dapat memesan air lewat web maupun smartphone android dari aplikasi yang sudah dirancang sehingga menghemat biaya dan juga pelanggan atau pengunjung web dapat memberi kritik dan saran kepada pengelola depot air minum.

3. Kasir atau admin melakukan verifikasi data calon pelanggan yang mendaftar melalui aplikasi.

4. Kasir atau admin menginput transaksi pelanggan yang melakukan pembelian di depot.

5. Pengantar dapat melihat data pesanan pelanggan lewat aplikasi smartphone android dan kemudian mengantarkan pesanan air.

6. Pengantar dapat menginput transaksi dari galon yang diantarkan dan dapat juga mengetahui bonus dari setiap inputan transaksi yang dilakukan pengantar.

7. Pemilik menerima laporan penjualan.

\subsection{Metode Pengumpulan Data}

Dalam menyelesaikan penelitian ini penulis memperoleh data yang diinginkan melalui pengumpulan data yang terdiri dari observasi, wawancara dan studi pustaka.

\subsection{Metode Pengembangan Sistem}

Pada penyusunan penelitian ini penulis menggunakan metode waterfall berikut tahapantahapan dalam metode waterfall menurut Pressman $(2001,29)$ :

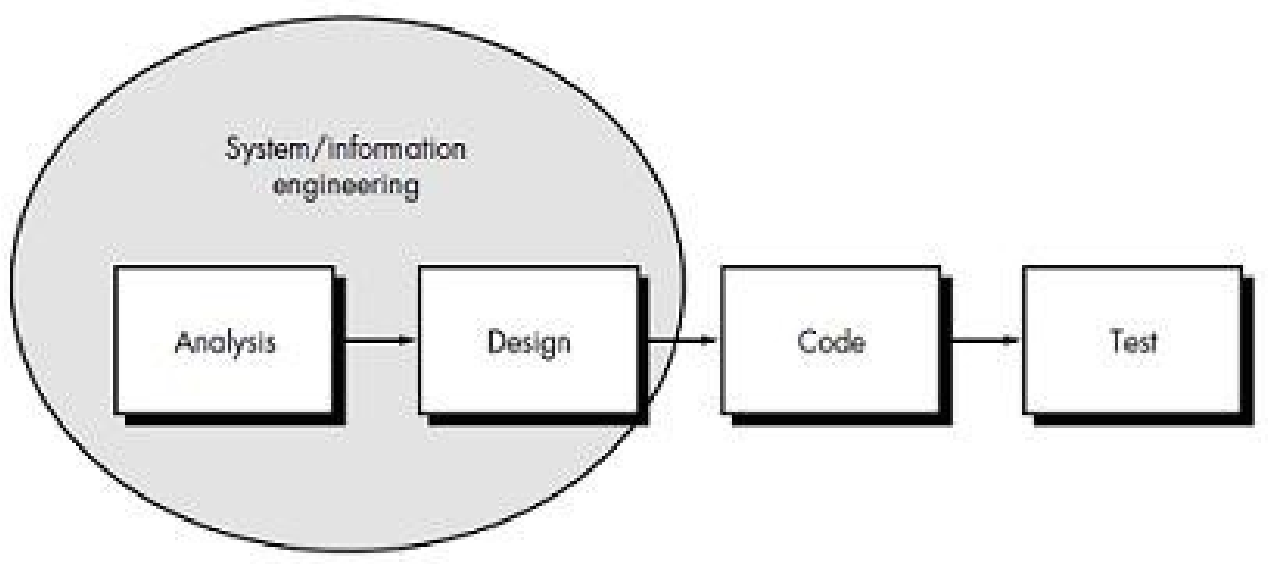

Gambar 1. Model Pengembangan Sistem dengan Waterfall 


\subsection{Metode Perancangan Sistem}

\section{Diagram Konteks}

Diagram konteks adalah diagram yang terdiri dari suatu proses dan menggambarkan ruang lingkup suatu sistem yang merupakan level tertinggi dari DFD dengan menggambarkan seluruh input ke sistem atau output dari sistem.

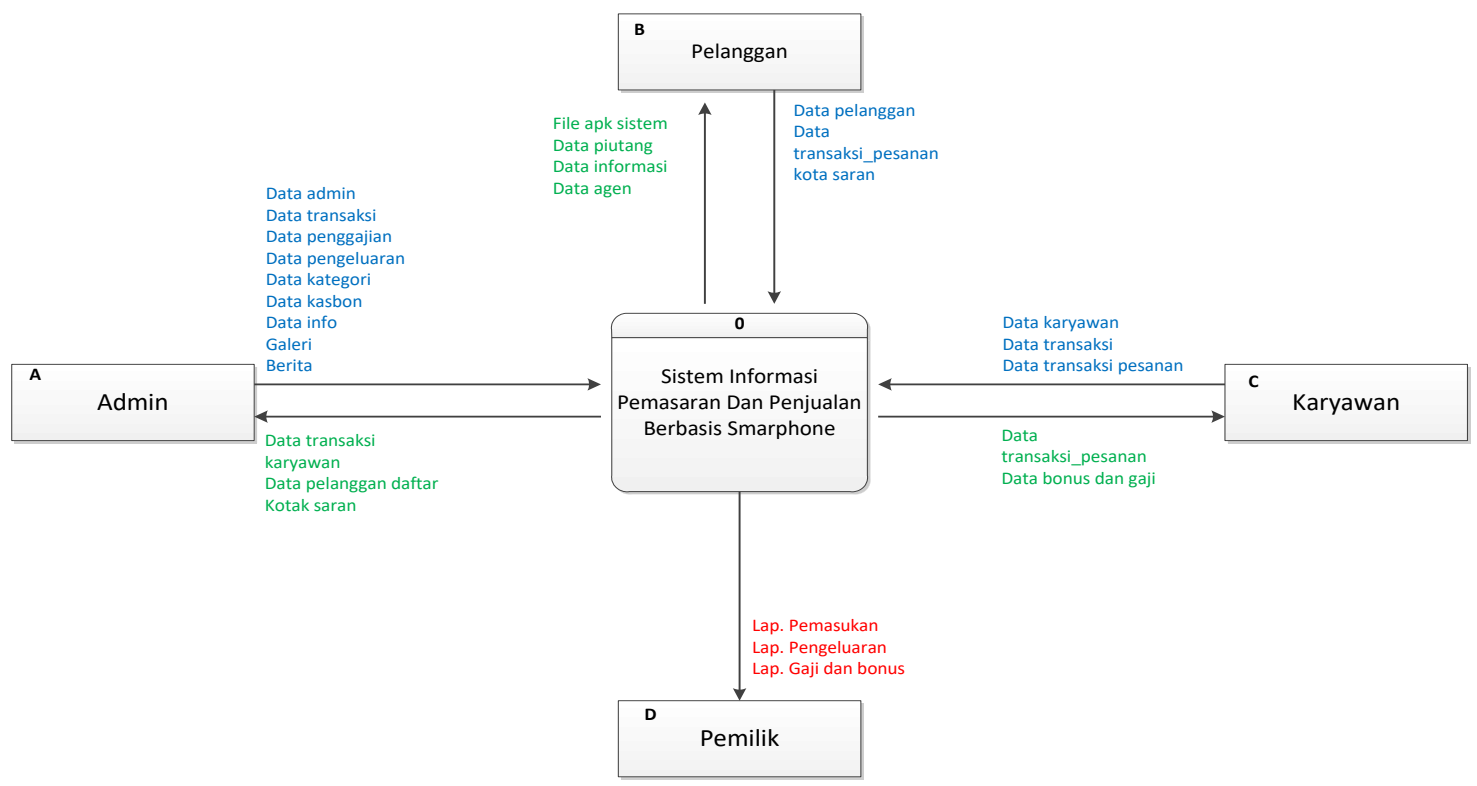

Gambar 2. Diagram Konteks

\section{Diagram HIPO}

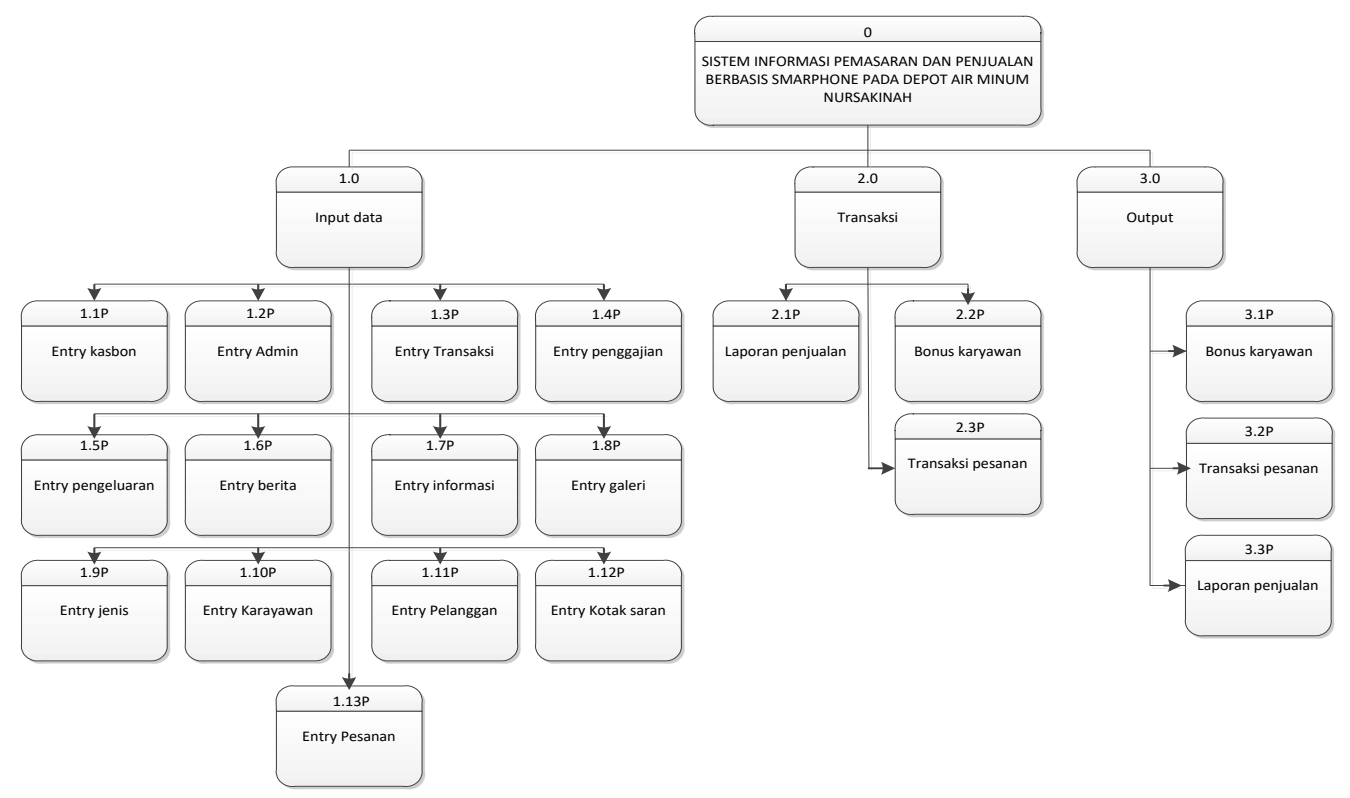

Gambar 3. Diagram HIPO 
Berdasarkan diagram diatas dapat dilihat bahwa admin memiliki peran penting dalam sistem informasi ini, mulai dari penginputan yang berhubungan dengan data pelanggan, data karyawan, pengelolaan data transaksi dan pesanan air minum, serta penyajian informasi dan laporan.

\section{Kesimpulan dan Saran}

\subsection{Kesimpulan}

Berdasarkan hasil penelitian dan pembahasan yang telah diuraikan pada bab-bab sebelumnya, maka dapat ditarik kesimpulan sebagai berikut:

1. Sistem informasi ini dapat memberikan informasi penjualan air minum isi ulang berbasis smartphone dan web.

2. Sistem informasi ini dapat memudahkan pelanggan untuk melakukan pemesanan air dengan menggunakan smartphone.

3. Sistem informasi ini dapat memudahkan pengantar untuk mengetahui bonus antaran dan

\subsection{Saran} mudah mengetahui pelanggan yang melakukan pemesanan air.

Setelah melakukan penelitian, adapun saran yang bisa disampaikan adalah :

1. Diharapkan Sistem Informasi Pemasaran dan Penjualan Berbasis Smartphone pada Depot Air Minum Nursakinah dapat meningkatkan pelayanan, pemasukan, dan meningkatkan kinerja pengantar karena adanya sistem bonus pergalon dan transparansi bonus.

2. Sistem ini masih banyak terdapat kekurangan baik dari perancangan dan implementasi sehingga peniliti masih membutuhkan arahan dan masukan dari pembimbing dan penguji.

\section{Daftar Pustaka}

[1] Jogiyanto, H.M. (2005), Analisis dan Desain Sistem Informasi: Pendekatan Terstruktur Teori dan Praktek Aplikasi Bisnis. Yogyakarta: Andi.

[2] Davis, Gordon. 1996. KerangkaDasar: SistemInformasiManajemen. Jakarta: PustakaBinamanPresindo

[3] Sutabri, Tata. 2005. SistemInformasi. Yogyakarta: Andi Offset.

[4] Marlinda. 2004. PerancanganSistem Database. Yogyakarta: Andi Offset

[5] Kadir, Abdul (2003), PengenalanSistemInformasi. Yogyakarta: Andi.

[6] Pardosi, Mico. 2006. Php Dan MySQL. Yogyakarta: Andi Offset

[7] Peranginangin, Kasiman. 2006. Relational Database Managemen. Yogyakarta: Andi Offset

[8] Kotler, Philip. (2000). ManajemenPemasaran di Indonesia.Analisis, Perencanaan, ImplementasidanPengendalian. SalembaEmpat. Jakarta

[9] Assauri, 2004. PemasaranBarang Dan Jasa. Jakarta: Rajagrafindo.

[10] William \& J. Stanton. 2005. Marketing Mix. Jakarta: KawanPustaka 